\title{
A STUDY ON A SPECIFIC TYPE OF POTTERY FROM THE ELAMITE ERA AND TOPONYMY OF ZABSHALI ${ }^{1}$
}

\begin{abstract}
So far, there have been no studies conducted extensively on the regions surrounding Elamite. One of the surrounding regions cover the north of present-day provinces Fars and Khuzestan as Elamite centers in the ancient era. The noteworthy point about these regions is their potentially rich metal mines. This has been mentioned in Mesopotamian inscriptions, mainly explaining the link between the Mesopotamian plain and the highlands of Elam. The present-day provinces, Khuzestan and Fars, have small potentials for metal mines. Hence, they only served as surrounding regions supplying the metals. However, little investigation has been done on the archeological data from the Elamite Era. It is crucial to carry out a historical study on these regions along with the archeological data to enlighten the dark spots in the Elamite Era and ultimately provide a toponymy of the Elamite cities. One instance of such archeological data involve various types of local pottery in Khuzestan (as a central city of Elam), which was compared through petrography against the samples recovered in Isfahan and Chaharmahal and Bakhtiari (as two surrounding regions). Finally, this paper intended to discuss more confidently the era in which this type of pottery was built and its origin in order to provide a toponymy of the Zabshali based on historical and archaeological data.
\end{abstract}

Keywords: Elamite Era, Pottery, Zabshali, Petrography, Isfahan.

\section{OVERVIEW OF THE SPECIFIC TYPE OF POTTERY AND REGIONS UNDER STUDY}

$\mathbf{T}$ he previous studies on the Elamite pottery generally focused on the form and shape of the artifacts ${ }^{2}$. From the perspective of fabric, very few studies have explored the Elamite pottery. The pottery type studied in this paper is orange (ranging from light brown to red) composed of a tempering material, sand and white particles. The core of this nonornamented, wheel-built pottery is black (Figure 1). In an investigation to outline the scope and boundaries of Haft Tapeh ancient city, a number of the Elamite pottery samples were recovered in certain layers dating back to the late ancient Elam (Sukalmah) and the Middle Elamite near the adobe structures of Haft Tapeh. In this light, the pottery type in this geographical scope can be particularly useful for comparison of similar artifacts found in Isfahan and Chaharmahal and Bakhtiari, both of which could be associated with the Elamite Era. This study focused on Asgaran and Saba as two regions

1 This paper was derived from a master's thesis by Ali Aarab at University of Tehran, supervised by M. E. Esmaeili Jelodar and advised by Alireza Khosrowzadeh.

2 CARTER 1979; CARTER 1992.

\section{Ali Aarab}

Department of Archaeology, University of Tehran aliaarab94@gmail.com

\section{Iraj Beheshti}

Iranian Center for Conservation

and Restoration Research

beheshti_i@yahoo.com

DOI: $10.14795 /$ j.v3i4.202

ISSN 2360 - 266X

ISSN-L 2360 - 266X 


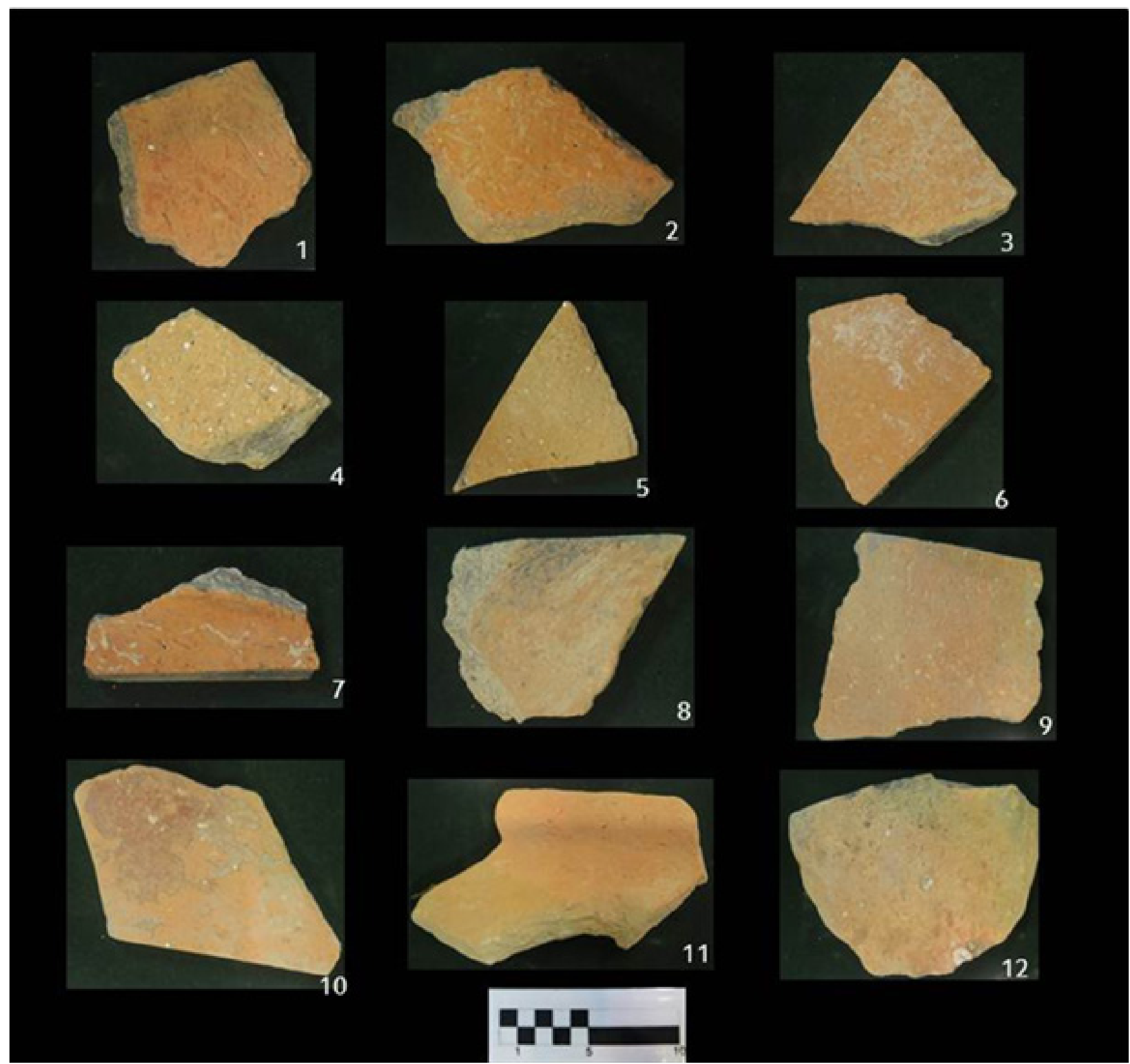

Figure 1. Pottery samples under study

in Isfahan and central part of Ardal in Chaharmahal and Bakhtiari (Figure 2). A total of 8 pottery samples were randomly selected from these regions. They were then compared in terms of fabric and composition against 4 counterparts found in archaeological layers of Haft Tapeh belonging to the Elamite Era.

\section{ZABSHALI}

A section of the script corresponding to the IsinLarsa Era mentions the Ishbi Era War (1921-1889 BC), the first king of the first dynasty of Isin, the sixth king listed in Simaški, speaking about the vastness of the sovereign territory for Simaški's defeated king (Kindato) covering Peshimeh to Zabshali and from Arava to Marhashi. Steinkeller demonstrated that the Elamite borders in this scripture are approximately based on the north-south and east-west directions. Accordingly, Pashimeh was located in the south, Zabshali in the north, Arava in the west and Marhashi in the east of Elam ${ }^{3}$. At the same time, a scripture from SuSuen indicates that Zabshali stretched from the boundaries of Anshan to the Upper Sea ${ }^{4}$. Moreover, several inscriptions from ŠuSuen suggest that Zabshali was destroyed in its seventh year of reign ${ }^{5}$. The royal inscriptions of Mesopotamia refer to tin as spillage from Zabshali and Simaški ${ }^{6}$. Ur Ninib, a king of Isin dynasty asserted to have conquered the lands of Zabshali and LU.SU with wild and nomadic peoples ${ }^{7}$. According to the Mesopotamian inscriptions, Zabshali was the most important city of Simaški rich in metal mines such as tin situated in north of Anshan and near the Upper Sea. The location of Anshan

3 STEINKELLER 1982; STEINKELLER 2007.

4 VALLAT 1993, 305.

5 POTTS 1999, 138.

6 SOLLBERGER/KUPPER 1971, IIIA4T.

7 OLMSTEAD 1919, 82 


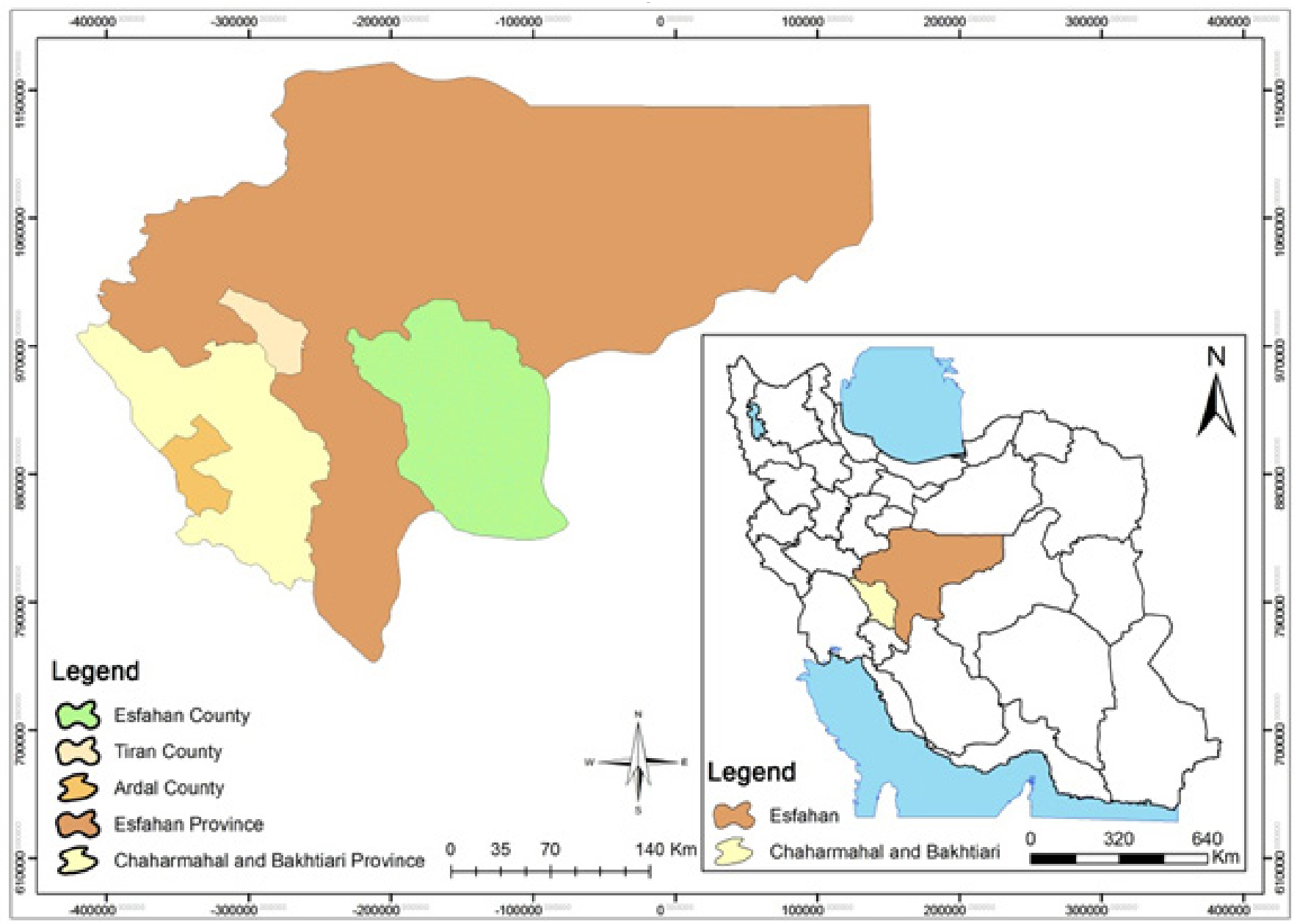

Figure 2. The locations of regions under study

in Tel-e Malyan is obvious according to previous studies ${ }^{8}$. According to the Mesopotamian inscriptions, Zabshali should be regarded a northern neighbor of Anshan toward the Upper Sea, a place rich in tin sources. As one of the cities across Simaški, Zabshali neighbored LU.SU. Concerning the Upper Sea, it should be noted that some scholars argue it is the same as present-day Caspian Sea since ŠuSuen applied this name for waters beyond Anshan ${ }^{9}$. If the Upper Sea is considered the Caspian Seat, then the land of Zabshali, stretching Anshan borders to the Upper Sea according to SuSuen scripts, will cover the north central provinces of Iran today. However, Zabshali was a part of the land of Elam, and should be searched for in remote areas. Moreover, none of the previous studies on these regions have ever pointed to the Elamite site in the north central provinces of Iran today. It is also worth noting that the ancient cuneiform scripts list the names of 59 figures who can be deemed Simaški residents. Of this, 12 names are either Elamite or associated to Elamite, while a person from Zabshali is called "In Da Su" which is an Elamite name ${ }^{10}$. According to these facts, the Simaški lands were not far from the present-day Fars province, the capital of the Elamite language ${ }^{11}$. The question still stands: where should we search for the Upper Sea? It can be suggested that present-day Gavkhouni drainage basin

\footnotetext{
8 HANSMAN 1972.

9 ZADOK 1991, 228.

10 ZADOK 1991, 228

11 POTTS 1999, 141.
}

was the Upper Sea during the Elamite Era. This drainage basin extends today for about 47 thousand hectares ${ }^{12}$. In the north of Anshan, the Iranian tin-rich resources can be traced only in southeast of Isfahan (near Gavkhouni), northwest of Yazd (near Gavkhouni) and northwest of Isfahan. Relying on previous investigations of mines and written resources, it can be argued that Isfahan and northern regions of Yazd province today constituted the major northeast and north territories of the Elamite state, where Zabshali was located.

\section{MICROSCOPIC STUDY ON POTTERY SAMPLES}

At this stage, a binocular polarizing microscope James Swift model was employed to perform a microscopic examination of the samples. This study involved a $4 \mathrm{X}$ magnification. The results of petrography have been displayed in Table (1).

Table 1 provides the minerals and compounds of pottery context in the first row. The first column displays the sample names, where gray represents Isfahan samples, blue represents, Khuzestan samples and yellow represents Chaharmahal and Bakhtiari samples. The presence of any minerals in the context of pottery samples has been indicated by $\left({ }^{*}\right)$, while the absence of minerals has been indicated by (-). Very low frequency of a mineral has been indicated by (tr). The last column provides the fabric or texture of pottery samples (Figure 3).

12 ZOUFAN/NORUZI 2008, 12. 


\begin{tabular}{|c|c|c|c|c|c|c|c|c|c|c|c|c|}
\hline N. Sample & $\begin{array}{l}Q_{z} \\
\text { (Clean) }\end{array}$ & $\begin{array}{l}\mathbf{Q}_{z} \\
\text { (Cloudy) }\end{array}$ & $P l g$ & $\begin{array}{l}A m \\
\& \\
P y\end{array}$ & Fe-oxid & Mica & Ce(Mic) & chert & M.Rock & $\begin{array}{l}\text { Silt } \\
\text { Shale }\end{array}$ & greq & Texaure \\
\hline ES.1 & * & * & $t r$ & $t r$ & * & $t r$ & * & * & - & - & - & Silt \\
\hline ES.2 & * & * & tr & - & * & $t r$ & $*$ & - & - & tr & * & Silt \\
\hline ES.3 & * & * & tr & * & * & $t r$ & * & - & - & * & - & Silt \\
\hline ES.4 & * & * & - & - & * & tr & $*$ & - & - & - & - & Silt \\
\hline ES.5 & * & * & * & - & * & $t r$ & * & - & $*$ & * & - & Porphyries \\
\hline KH.1 & * & * & tr & * & * & $t r$ & * & - & - & - & - & Porphyries \\
\hline KH.2 & * & * & $t r$ & - & * & tr & * & - & - & - & - & Silt \\
\hline KH.3 & * & * & $t r$ & * & * & $t r$ & $*$ & - & - & - & * & Porphyries \\
\hline KH.5 & * & * & - & - & * & tr & $*$ & - & - & - & - & Ponphyries \\
\hline CH.1 & * & * & $t r$ & * & * & $t r$ & * & - & - & - & * & Ponphyries \\
\hline CH.2 & * & * & - & - & * & $t r$ & * & - & - & - & - & Silt \\
\hline CH.3 & * & * & - & - & * & tr & * & - & - & - & - & Silt \\
\hline
\end{tabular}

Abbreviations: Qz (Clean)=quartz phenocrysts. Qz (Cloudy)=cloudy and polycrystalline quartz. Plg=plagioclase. Am\&Py=amphibole and pyroxene. Fe-oxid=iron oxide. $\mathrm{Cc}=$ calcite. M-Rock=metamorphic rock. Silt\&Shale=silt and shale rock fragments, Grog=clay parts added to pottery.

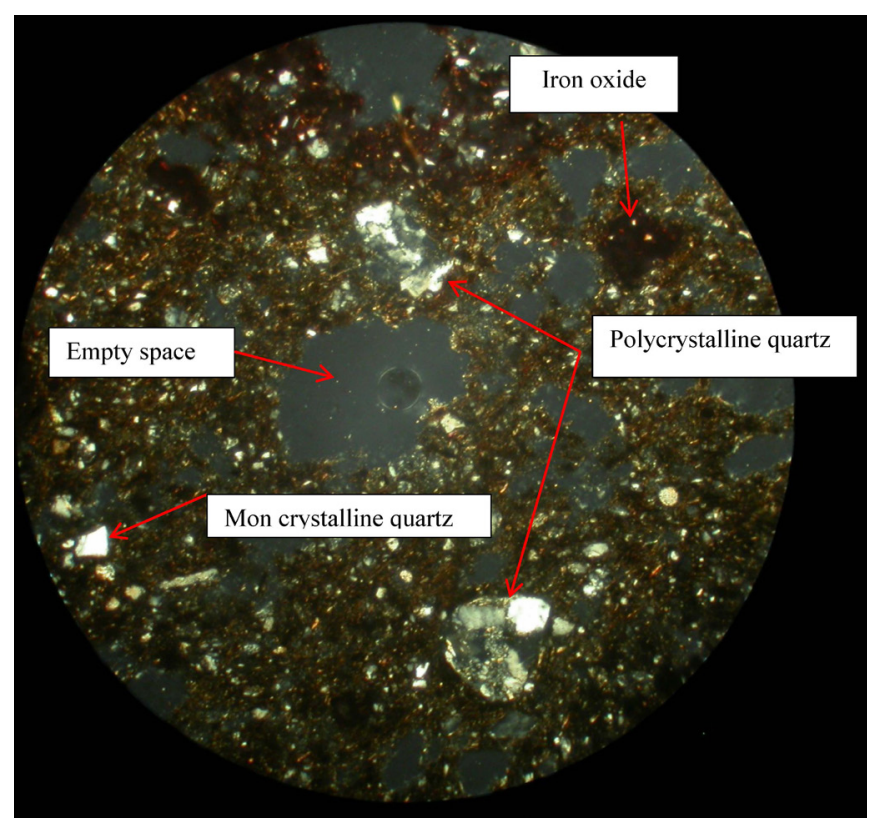

Finally, the compositions of the pottery samples demonstrate their common origins except ES.5, (Figure 5) whereas the difference between other pottery samples generally lies in the frequency of each constituent element (Figure 4). According to the constituent element of pottery samples, this pottery type does not originate from Khuzestan Plain, but it can rather be traced in Zagros Mountains.

\section{CONCLUSIONS}

According to the above discussion, the specific pottery type in this study indicated a remarkable frequency in Isfahan and Chaharmahal and Bakhtiari. Moreover, it proved to be similar to counterparts recovered at Haft Tapeh (Khuzestan) in terms of fabric, production technique and curing temperature. It is essential to point out the pottery types across the northern Elamite centers which have been rarely explored so far. The specific pottery type examined in this paper can definitely be considered an Elamite artifact. It should originate from the Zagros Mountains in the north of Khuzestan (Bakhtiari highlands). That is perhaps why this type of pottery is less abundant in Khuzestan as opposed to Isfahan and Chaharmahal and Bakhtiari. Therefore, it can be argued that the Elamite were involved in dominated 

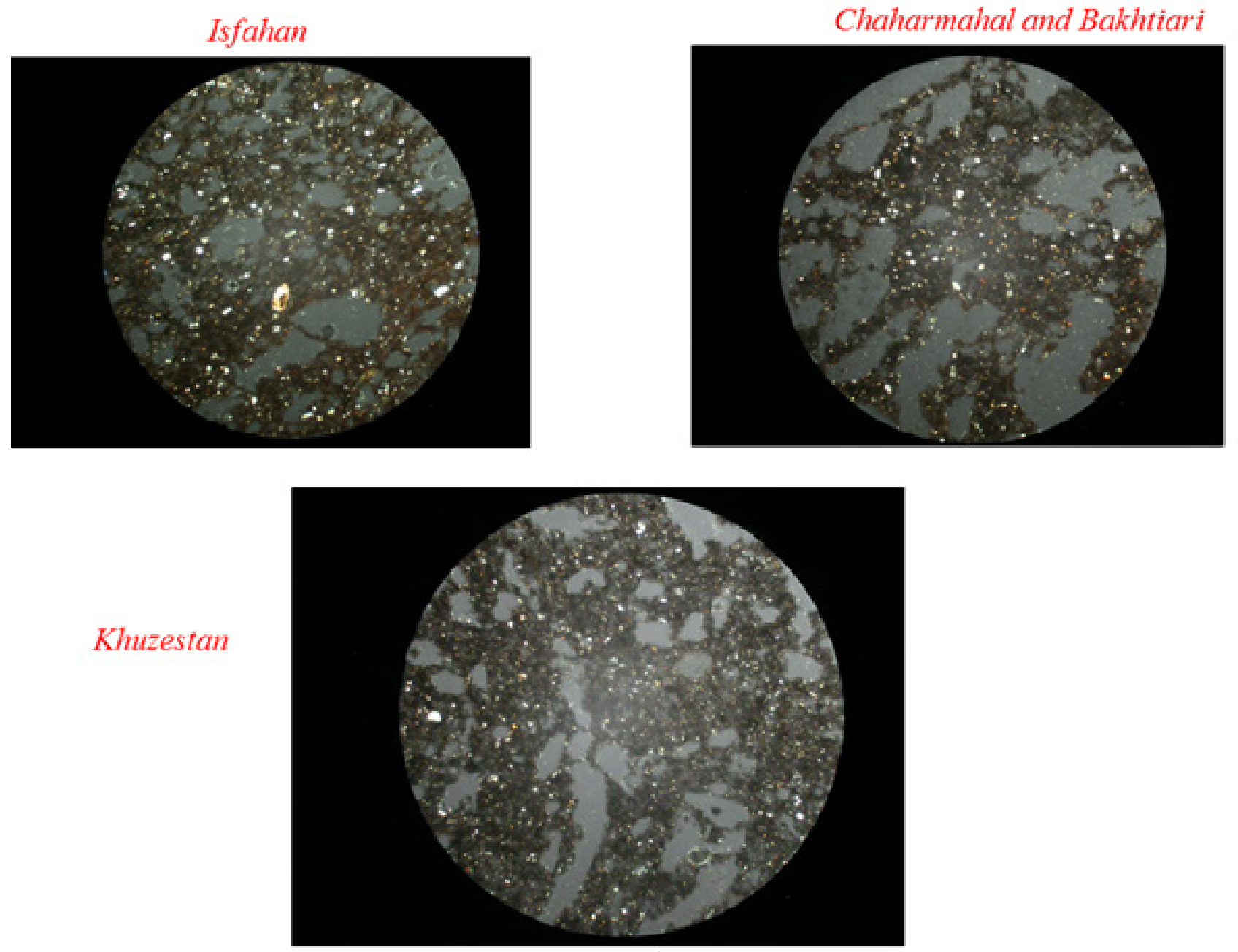

Figure 4. Fabric similarities between pottery samples recovered in Khuzęstan, Isfahan and Chaharmahal and Bakhtiari.

Isfahan and Chaharmahal and Bakhtiari, while delving into the toponymy of Elamite cities such as Zabshali in certain

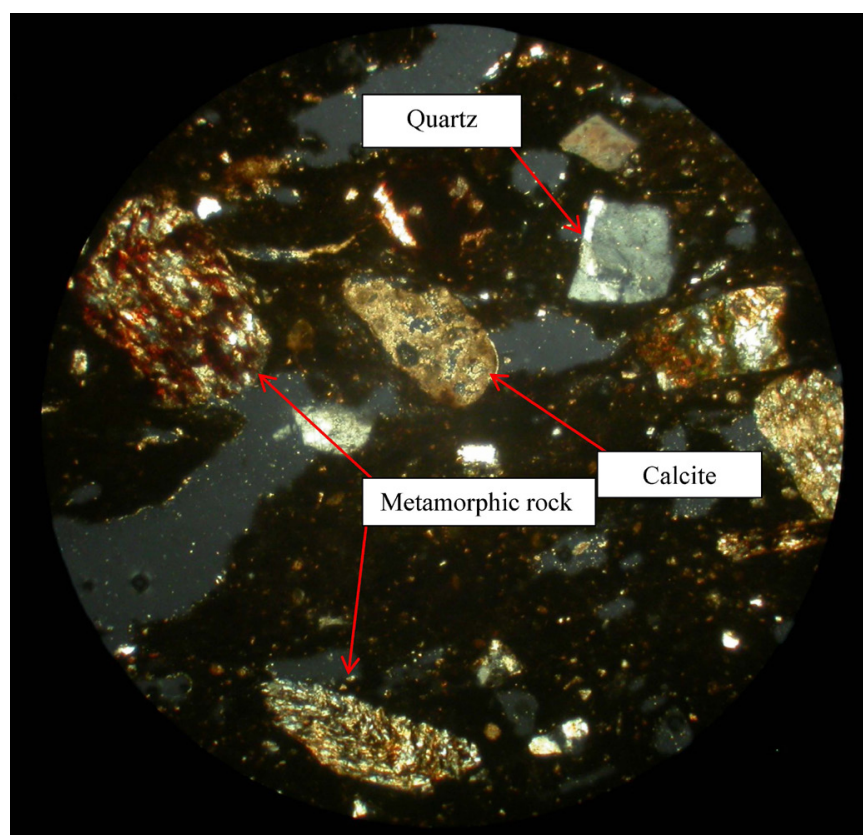

Figure 3. SEM image of Sample ES.5, 4X magnification, XPL, porphyritic fabric, large fragments of calcite, metamorphic rock and quartz in the clay context of pottery. parts of Isfahan province.The regions never explored from that very perspective can set out a new avenue of Elamite research into these Iranian provinces. Finally, it is recommended that future studies focus on northern regions of Elamite centers including the present-day Isfahan, Yazd and Chaharmahal and Bakhtiariti so as to clarify many of the archaeological ambiguities of Elamite Era. After all, an in-depth investigation of Mesopotamian inscriptions can help scholars realize the importance of these regions, while revealing their archaeological capacities.

\section{REFERENCES}

CARTER 1979

Carter, E., Elamitr pottery: ca 2000-1000 B.C, Journal of Near Eastern Studies 38/2, 111-128.

\section{CARTER 1992}

Carter, E., Ceramics: VIII, The Early Bronze age in southwestern and southern Persia. In: Yarshater, E. (ed.), Encyclopedia Iranica 5/3 (Costa Mesa, California: Mazda Publisher).

\section{HANSMAN 1972}

Hansman, J., Elamites, Aghaemenians and Anshan, Iran 10, 101-125.

\section{OLMSTEAD 1919}

Olmstead, A. T., The Babylonian Empire, The American Journal of Semitic Languages and Literatures 35/2, 65-100. 
POTTS 1999

Potts, D. T, The Archeology of Elam. Formation and Transformation of an Ancient Iranian State (Cambridge: Cambridge press).

SOLLBERGER/KUPPER 1971

Sollberger, E./Kupper, J. R., Inscriptions royales sumeriennes et akkadiennes (Paris: Cerf).

\section{STEINKELLER 1982}

Steinkeller, P., The question of Marhaši: A contribution to the historical geography of Iran in the third millennium BC, Zeitschrift für Assyriologie und vorderasiatische Archäologie 72/2, 237-265.

\section{STEINKELLER 2007}

Steinkeller, P., 2007, New light on Šimaški and its rulers, Zeitschrift für Assyrologie und vorderasiatische Archäologie 97/2, 215-232.

VALLAT 1993

Vallat, F., Les noms géographiques des sources suso-élamites. Répertoire géographique des textes cunéiformes 11 (Wiesbaden: Dr. Ludwig Reichert Verlag).

ZADOK 1991

Zadok, R., Elamite Onomastics, Studi Epigrafici e Linguistici sul Vicino Oriente Antico 8, 225-237.

ZOUFAN/NORUZI 2008

Zoufan, J./Noruzi, G., Gavkhouni, Iranian Ministry of Interior, Isfahan Provincial and Governance Department. 